\title{
PENGARUH TERAPI MUSIK KLASIK TERHADAP KECEMASAN PASIEN PRE OPERASI DI INSTALASI BEDAH PUSAT RSUP H. ADAM MALIK MEDAN TAHUN 2018
}

\author{
Basri $^{1}$, Denny Lisbetty Lingga ${ }^{2}$ \\ ${ }^{1}$ Institute Kesehatan Sumatera Utara $;{ }^{2}$ Institute Kesehatan Sumatera Utara \\ Email: hasanb77@yahoo.com
}

\begin{abstract}
Anxiety that is not handled properly can cause physical and psychological changes that ultimately can improve sympathetic nervous work and will increase heart rate, breath frequency, blood pressure, cold sweats, heartburn, urinary disorders, and generally reduce the energy level on patients thus harming the patient itself. In preoperative times patients face various stressors that cause anxiety. The development of music has a therapeutic effect in overcoming mood disorders, such as anxiety. This study aims at the influence of classical music therapy on preoperative patient anxiety at the Central Surgery Installation RSUP H. Adam Malik Medan. The type of research used in this research is quasi-experiment method through one group pretest post test design approach with 32 pre-operation respondents aged over 18 years. Data were collected using questionnaires. The result of bivariate analysis of this study is the influence of music therapy on preoperative anxiety in the Central Surgery Installation of RSUP. $H$. Adam Malik Medan shows $p$ value $=0.000$, and $0.000<0,05$ which means there is significant influence from giving classical music therapy on $T$ test that is before given music therapy got result of test of $T 382.531$ become 301.288 (81,243). The results of this study It is expected to be a consideration of hospitals or nurses to make music therapy as one of nursing intervention in helping alleviate anxiety in preoperative patients who experience anxiety.
\end{abstract}

\section{Keywords: Classical music therapy; anxiety level; are operation}

\section{PENDAHULUAN}

Kecemasan merupakan suatu respon terhadap situasi tertentu yang mengancam dan juga hal yang normal menyertai perkembangan, perubahan, pengalaman baru yang belum pernah dilakukan, serta dalam menentukan identitas diri dan arti hidup. Kecemasan menjadi reaksi yang dapat dialami siapapun. Namun, cemas yang berlebihan apalagi yang sudah gangguan akan menghambat fungsi seseorang dalam kehidupannya (Kaplan \& Saddock, 2010).
Kecemasan yang tidak ditangani dengan baik dapat menimbulkan adanya perubahan secara fisik maupun psikologis yang akhirnya dapat meningkatkan kerja saraf simpatis dan akan terjadi peningkatan denyut jantung, frekuensi nafas, tekanan darah, keringat dingin, merasa mulas, gangguan perkemihan, dan secara umum mengurangi tingkat energi pada pasien sehingga merugikan pasien itu sendiri. Kecemasan merupakan gejala yang paling sering muncul pada tahap pre operasi (Savitri, dkk, 2016). 
Kecemasan pasien pada masa pre operasi antara lain dapat berupa khawatir terhadap nyeri setelah pembedahan, perubahan fisik (menjadi buruk rupa dan tidak berfungsi normal), keganasan (bila diagnosa yang ditegakan belum pasti), operasi akan gagal, mati saat dilakukan anestesi, mengalami kondisi yang sama dengan orang lain yang mempunyai penyakit yang sama, menghadapi ruang operasi, peralatan bedah dan petugas (Perry \& Potter, 2010).

Anxiety and Depression Association of American (ADAA, 2014), kecemasan diperkirakan mempengaruhi 1 dari setiap 25 orang Inggris. Perempuan lebih banyak dari pada laki-laki, dan kondisi ini lebih sering terjadi pada orang usia antara 35-55. American Psychiatri Association (APA) dalam Halgin (2012), kecemasan mempengaruhi $8,3 \%$ dari populasi dan biasanya terjadi pada wanita $55-60 \%$. Survei komunitas menunjukkan sekitar $3-5 \%$ orang dewasa mengalami kecemasan, dengan prevalensi seumur hidup lebih dari 25\%. Sekitar 15\% pasien yang akan dioperasi dan 25\% yang berobat biasanya gelisah. Gangguan kecemasan biasanya dimulai pada awal masa dewasa, antara 15 dan 25 tahun, akan semakin meningkat setelah usia 35 tahun. Perempuan lebih sering terkena dari pada laki-laki, dengan rasio sampai 2:1 pada beberapa survei (Puri, 2012).

Pada masa pre operasi pasien menghadapi berbagai stresor yang menyebabkan kecemasan. Menurut Carpenito (2002), menyatakan bahwa 90\% pasien pre operasi berpotensi mengalami kecemasan. Menurut Yulanda dalam Efendi (2008), penelitiannya menyebutkan bahwa sebanyak $91,43 \%$ mengalami kecemasan, sementara itu dalam penelitiannya yang dilakukan pada 41 orang diperoleh informasi bahwa terdapat sebanyak $9,8 \%$ pasien mengalami kecemasan berat, $31,7 \%$ pasien dengan kecemasan sedang, $53,7 \%$ pasien dengan ringan dan $4,9 \%$ pasien tidak mengalami kecemasan.

Penanganan kecemasan dapat dilakukan dengan pemberian terapi farmakologi seperti antiansietas atau antidepresan (Kaplan \& Sadock, 2010). Selain terapi farmakologi, sekarang juga telah banyak dikembangkan terapi nonfarmakologi dalam mengurangi tingkat kecemasan yang dapat dilakukan oleh perawat, salah satunya adalah terapi musik. Terapi musik adalah suatu proses yang menghubungkan antara aspek penyembuhan musik itu sendiri dengan kondisi dan situasi fisik/tubuh, emosi, mental, spiritual, kognitif dan kebutuhan sosial seseorang (Natalina, 2013). 
Perkembangan musik memiliki efek terapi dalam mengatasi gangguan suasana hati, seperti kecemasan. Kepercayaan spiritual pun memainkan peranan penting dalam menghadapi kecemasan. Terapi komplementer diperlukan untuk menurunkan efek dari penggunaan obat-obatan dalam mengatasi kecemasan atau terapi pelengkap yang dapat menangani tingkat kecemasan. Terapi komplementer merupakan terapi holistis atau terapi nonbiomedis. Salah satu dari terapi komplementer yang sedang banyak dikembangkan di bidang kesehatan saat ini adalah terapi musik. Penelitian yang dilakukan oleh Rahayu, Andiyani., dkk, (2014), ada perbedaaan yang signifikan antara tingkat kecemasan pasien pre operasi SC sebelum dan sesudah diberikan terapi musik. pemberian terapi musik dapat menurunkan tingkat kecemasan pada pasien Pre Operasi SC.

Penelitian Astuti dan Merdekawati (2016), Sebelum terapi musik klasik diberikan, rata-rata skala nyeri pada pasien post operasi adalah 6 dan setelah diberikan terapi musik klasik rata-rata skala nyeri pada pasien post operasi adalah 3. Ada pengaruh terapi musik terhadap penurunan skala nyeri pada pasien post operasi

Studi pendahuluan yang peneliti lakukan terhadap 11 orang pasien yang akan dilakukan tindakan operasi, ternyata 9 mengalami tingkat kecemasan berat, dan 2 orang pasien mengalami kecemasan sedang. Kecemasan yang dialami pasien mempunyai bermacammacam alasan diantaranya adalah cemas menghadapi ruangan operasi dan peralatan operasi, cemas menghadapi body image yang berupa cacat anggota tubuh, cemas dan takut mati saat dibius, cemas bila operasi gagal, cemas masalah biaya yang membengkak. Beberapa pasien yang mengalami kecemasan berat terpaksa menunda jadwal operasi karena pasien belum siap mental menghadapi operasi. Selain itu data pendukung yang diperoleh bahwa pasien yang akan menghadapi operasi rata-rata mengalami peningkatan tekanan darah.

\section{METODE}

Jenis penelitian yang digunakan adalah menggunakan desain quasiexperiment melalui pendekatan one group pretest post test design (Campbell \& Cronbach, 2002). Penelitian dilakukan pada satu kelompok subyek yang untuk mengidentifikasi pengaruh sebelum dan sesudah pemberian terapi musik klasik terhadap kecemasan pasien pre operasi di Instalasi Bedah Pusat RSUP H. Adam Malik Medan. Waktu penelitian dilakukan bulan Januari 2018.

Populasi penelitian ini adalah semua pasien pre operasi di Instalasi Bedah 
Pusat RSUP H. Adam Malik Medan. sebanyak 127 orang.

Teknik pengambilan sampel dengan cara purposive sampling. Menurut Arikunto (2010) bila total populasi lebih dari 100 maka pengambilan sampel 10\% - $15 \%$ dan $20 \%$ - $25 \%$ dari total populasi, dimana total populasi 127 pasien, didapatkan jumlah sampel yang diambil dalam penelitian ini adalah sebanyak 32 orang.

Aspek pengukuran dilakukan terhadap kecemasan dengan menggunakan instrumen Zung SelfRating Anxiety Scale Z(SAS/ SRAS) (Hawari, 2011) yang telah dimodifikasi.

Analisa data meliputi data univariat dan bivariat. Analisa univariat menghasilkan distribusi dan persentase dari tiap variabel. Analisis bivariat dalam penelitian ini mengunakan uji paired samples t-test untuk melihat perbedaan tingkat kecemasan pasien pre operasi sebelum dan sesudah pemberian terapi musik klasik. Untuk melihat pengaruh terapi musik klasik terhadap kecemasan pasien pre operasi digunakan uji independent samples t-test.

\section{HASIL DAN PEMBAHASAN}

\section{Hasil}

Penelitian ini dilakukan selama 1 bulan, yaitu selama bulan Februari 2018 di Ruang Instalasi Bedah Pusat RSUP. H. Adam Malik Medan. Penyajian data meliputi deskriptif data demografi responden, distribusi dan frekuensi usia, jenis kelamin, pendidikan, pekerjaan, kecemasan pasien pre terapi musik dan post terapi musik klasik.

\section{Data Demografi}

Tabel 1.

Distribusi Frekuensi dan Persentase Data Demografi Responden di Instalasi Bedah Pusat RSUP. H. Adam Malik Medan $(n=32)$

\begin{tabular}{|c|c|c|}
\hline Data Demografi & $f$ & $\%$ \\
\hline \multicolumn{3}{|l|}{ Jenis Kelamin } \\
\hline Laki-laki & 22 & 68,8 \\
\hline Perempuan & 10 & 31,2 \\
\hline Total & 32 & 100,0 \\
\hline \multicolumn{3}{|l|}{ Usia } \\
\hline 18-35 tahun & 3 & 9,4 \\
\hline 36-50 tahun & 12 & 37,5 \\
\hline$>50$ tahun & 17 & 53,1 \\
\hline Total & 32 & 100,0 \\
\hline \multicolumn{3}{|l|}{ Pendidikan } \\
\hline SD/SMP & 9 & 28,1 \\
\hline SMA & 13 & 40,6 \\
\hline Akademi/PT & 10 & 31,3 \\
\hline Total & 32 & 100,0 \\
\hline \multicolumn{3}{|l|}{ Pekerjaan } \\
\hline PNS/Polri & 11 & 34,4 \\
\hline Wiraswasta & 11 & 34,4 \\
\hline \multicolumn{3}{|l|}{ Mengurus } \\
\hline Rumah & 4 & 12,5 \\
\hline \multicolumn{3}{|l|}{ Tangga } \\
\hline Lain-lain & 6 & 18,8 \\
\hline Total & 32 & 100,0 \\
\hline
\end{tabular}

Berdasarkan hasil penelitian dari 32 responden menunjukkan bahwa mayoritas pasien berjenis kelamin lakilaki yaitu 22 orang $(68,8 \%)$, mayoritas pasien berusia $>50$ tahun yaitu 17 orang $(53,1 \%)$, mayoritas pendidikan terakhir pasien SMA yaitu 13 orang (40,6\%), dan mayoritas pekerjaan responden PNS/Polri dan Wiraswasta sebanyak masing-masing 11 orang $(34,4 \%)$. 
Kecemasan Pasien Pre Operasi Sebelum Diberikan Terapi Musik Klasik

Tabel 2.

Distribusi Kecemasan pasien Pre Operasi Sebelum Diberikan Terapi Musik Klasik di Instalasi Bedah Pusat RSUP. H. Adam Malik Medan (n=32)

\begin{tabular}{lcc}
\hline $\begin{array}{c}\text { Tingkat } \\
\text { Kecemasan }\end{array}$ & $\begin{array}{c}\text { Frekuensi } \\
(\boldsymbol{f})\end{array}$ & $\begin{array}{c}\text { Persentase } \\
(\boldsymbol{\%})\end{array}$ \\
\hline Ringan & 0 & 0,0 \\
Sedang & 24 & 75,0 \\
Berat & 8 & 25,0 \\
Panik & 0 & 0,0 \\
$\quad$ Total & 32 & 100,0 \\
\hline
\end{tabular}

Berdasarkan tabel tentang kecemasan pasien pre operasi sebelum diberikan terapi musik klasik di Instalasi Bedah Pusat RSUP. H. Adam Malik Medan didapatkan mayoritas pasien berada di kecemasan sedang yaitu 24 orang (75\%), kecemasan berat sebanyak 8 orang (25\%), dan tingkat kecemasan ringan dan panik tidak ada $(0 \%)$.

Kecemasan Pasien Pre Operasi Setelah Diberikan Terapi Musik Klasik

Tabel 3.

Distribusi Kecemasan pasien Pre Operasi Setelah Diberikan Terapi Musik Klasik di Instalasi Bedah Pusat RSUP. H. Adam Malik Medan $(\mathrm{n}=32)$

\begin{tabular}{ccc}
\hline $\begin{array}{c}\text { Tingkat } \\
\text { Kecemasan }\end{array}$ & $\begin{array}{c}\text { Frekuensi } \\
(\boldsymbol{f})\end{array}$ & $\begin{array}{c}\text { Persentase } \\
(\mathbf{\%})\end{array}$ \\
\hline Ringan & 10 & 31,3 \\
Sedang & 20 & 62,5 \\
Berat & 2 & 6,2 \\
Panik & 0 & 0,0 \\
Total & 32 & 100,0 \\
\hline
\end{tabular}

Berdasarkan hasil penelitian dari 32 responden menunjukkan bahwa terdapat perubahan tingkat kecemasan pasien ringan $(0,0 \%)$ menjadi 10 orang $(31,3 \%)$, Sedang sebanyak 24 orang $(75 \%)$ menjadi 20 orang $(62,5 \%)$ dan berat sebanyak 8 orang (25\%) menjadi 2 orang $(6,2 \%)$.

Pengaruh Terapi Musik Klasik terhadap Tingkat Kecemasan Pasien Pre Operasi

Tabel 6.

Pengaruh Terapi Musik Klasik terhadap Tingkat Kecemasan Pasien Pre Operasi di Instalasi Bedah Pusat RSUP. H. Adam Malik Medan $(n=32)$

\begin{tabular}{|c|c|c|c|c|c|c|c|c|}
\hline \multirow[b]{2}{*}{ No. } & \multirow[b]{2}{*}{ Variabel } & \multicolumn{7}{|c|}{ Nilai $\boldsymbol{U} j i \boldsymbol{t}$} \\
\hline & & $t$ & $d f$ & $S D$ & $\begin{array}{c}\text { Std } \\
\text { Error }\end{array}$ & Mean & $\begin{array}{c}\text { Mean } \\
\text { Dif }\end{array}$ & $\begin{array}{c}P \\
\text { value }\end{array}$ \\
\hline \multirow[t]{5}{*}{1} & Kecemasan Pre & & & & & & & \\
\hline & Operasi & 382,5 & 31 & 0,4 & 0,078 & 2,25 & 29,750 & \\
\hline & Sebelum & & & & & & & \\
\hline & Terapi Musik & & & & & & & 0,00 \\
\hline & Mozart & & & & & & & \\
\hline \multirow[t]{4}{*}{2} & Kecemasan Pre & & & & & & & \\
\hline & Operai & 301,3 & 31 & 0,6 & 0,100 & 1,75 & 30,250 & \\
\hline & SesudahTerapi & & & & & & & \\
\hline & Musik Mozart & & & & & & & \\
\hline
\end{tabular}

rata-rata (mean) skor sebelum diberikan terapi musik 2,25 dan mean diferensi 29.750 dengan simpangan baku (SD) 0,4 dan mean skor setelah pemberian terapi musik 1,75 dan mean Diferensi 30.250 dengan SD 0.568.

Pengaruh terapi musik terhadap kecemasan pre operasi di Instalasi Bedah Pusat RSUP. H. Adam Malik Medan menunjukkan $\mathrm{p}$ value $=0.00$, dan $0.00<0,05$ yang berarti ada pengaruh yang signifikan dari pemberian terapi musik klasik pada uji $\mathrm{T}$ yaitu sebelum diberikan terapi musik didapat hasil uji $\mathrm{T}$ (t hitung) 382,5 menjadi (t Hitung) 301,3 dengan perolehan $\mathrm{p}$ value 0.00 
(nilai ini lebih kecil dari 0.05), dimana terdapat selisih thitung (382,5-301,3 $=81,2)$. Hal ini menunjukkan ada hubungan pemberian terapi musik untuk menurunkan kecemasan pasien pre operasi.

\section{Pembahasan}

\section{Data Demografi}

Berdasarkan penelitian ini diketahui bahwa jenis kelamin terbanyak adalah laki-laki yaitu 22 orang $(68,8 \%)$. Secara psikologis karena laki-laki dalam melakukan sesuatu selalu menggunakan rasio/pikiran yang matang sebelum dilakukan operasi dan merasa sebagai kepala keluarga yang memiliki tanggung jawab yang besar (Hurlock, 2006 dalam Dewi, 2012).

Berdasarkan penelitian ini dapat diketahui bahwa usia terbanyak adalah > 50 tahun yaitu 17 orang $(53,1 \%)$. Hal tersebut sesuai teori yang di kemukakan oleh Notoadmojo (2012), bahwa semakin cukup umur maka tingkat kematangan dan kekuatan seseorang akan lebih matang dalam berfikir, sehingga kecemasan lebih banyak pada usia dewasa.

Berdasarkan penelitian ini dapat diketahui bahwa pendidikan terbanyak adalah SMA yaitu 13 orang $(40,6 \%)$. Pendidikan dapat mempengaruhi seseorang termasuk perilaku seseorang akan pola hidup terutama dalam motivasi untuk sikap berperan serta. Semakin tinggi pendidikan semakin tinggi pula pengetahuan (Notoadmojo, 2012). Pendidikan yang lebih tinggi dengan pengetahuan yang baik mampu menurunkan tinggkat kecemasan pasien yang akan dilakukan operasi. (Dewi, 2012).

Berdasarkan penelitian ini dapat diketahui bahwa pekerjaan terbanyak adalah PNS dan wiraswasta yaitu masing-masing 11 orang $(34,4 \%)$. Seseorang yang bekerja swasta karena tuntutan penampilan pada pekerjaannya menyebabkan kecemasan karena mempunyai pekerjaan yang penting dan memerlukan aktivitas, akan merasa terganggu apabila tidak dapat sembuh seperti sedia kala, karena dituntut untuk penampilannya dan mempengaruhi perannya (Christian, 2005, dalam Afitria, 2012).

\section{Kecemasan pasien Pre Operasi Sebelum diberikan Terapi Musik Klasik}

Hasil penelitian ini menunjukkan bahwa tingkat kecemasan sebelum dilakukan terapi musik klasik pada pasien pre operasi mayoritas berada pada tingkat kecemasan sedang yaitu sebanyak 24 orang (75\%), kecemasan berat sebanyak 8 orang (25\%), dan tingkat kecemasan ringan dan panik tidak ada (0\%). Hasil penelitian ini sejalan dengan penelitian yang 
dilakukan oleh Devi (2008), bahwa kecemasan pasien sebelum intervensi berada pada kecemasan sedang di RS Cipto Mangunkusumo Jakarta.

Kecemasan pre operasi disebabkan karena mereka tidak tahu konsekuensi pembedahan dan takut terhadap prosedur pembedahan itu sendiri. Pasien yang cemas sering mengalami ketakutan atau perasaan yang tidak tenang seperti ketakutan akan hal yang tidak diketahui, misalnya menghadapi pembedahan, anatesi, keuangan, tanggung jawab keluarga, nyeri, ketakutan akan konsep diri dan bahkan kematian. Kecemasan dapat menimbulkan adanya perubahan secara fisik maupun psikologis (Muttaqin \& Sari, 2009).

\section{Kecemasan pasien Pre Operasi Sesudah diberikan Terapi Musik Klasik}

Hasil penelitian ini menunjukkan bahwa tingkat kecemasan setelah dilakukan terapi musik klasik pada pasien pre operasi bahwa terdapat perubahan tingkat kecemasan pasien ringan $(0,0 \%)$ menjadi 10 orang $(31,3 \%)$, Sedang sebanyak 24 Orang (75\%) menjadi 20 orang $(62,5 \%)$ dan berat sebanyak 8 orang (25\%) menjadi 2 orang $(6,2 \%)$.

Pada Pasien pre operasi maka sebelum pembedahan kita dapat membantu pasien dalam menghilangkan ketegangan atau kecemasan yaitu dengan cara memberikan latihan relaksasi dalam membantu mengkontrol kecemasan. Terapi relaksasi terdiri dari berbagai macam jenis, salah satunya dengan mendengarkan musik. Musik merupakan getaran udara yang harmonis, saraf telinga yaitu saraf koklearis menangkapnya, diteruskan ke otak dan di otak musik akan mempengaruhi hipofisis untuk melepaskan endorphin sehingga dapat mengurangi rasa nyeri. Rangsangan musik juga dapat mengaktivasi jalurjalur spesifik di dalam beberapa otak, seperto limbic yang berhubungan dengan perilaku emosional, sistem limbik teraktivasi dan individu menjadi rileks (Djohan, 2006)

\section{Pengaruh Terapi Musik Klasik Terhadap Kecemasan Pasien Pre Operasi}

Berdasarkan penelitian ini kecemasan sebelum diberikan intervensi didapatkan mayoritas pasien berada di kecemasan sedang yaitu 24 orang (75\%) dan didapatkan mayoritas pasien berada di kecemasan sedang yaitu 20 orang $(62,5 \%)$ dan kecemasan ringan dari sebelumnya tidak ada menjadi sebanyak 10 orang $(31,4 \%)$.

Berdasarkan penelitian ini didapatkan kecemasan sebelum intervensi dengan nilai rata-rata (mean) 2.25 sehingga standart deviasi 0,440. Sedangkan kecemasan sebelum intervensi dengan 
nilai rata-rata (mean) 1,75 sehingga standar deviasi 0,568. Pada hasil penelitian ini menggunakan uji $\mathrm{T}$ menunjukan nilai $\mathrm{p}$ value 0,00 atau < 0,05 maka dapat disimpulkan ada perbedaan tingkat kecemasan pada pasien pre operasi sebelum dan sesudah pemberian terapi musik klasik. Berarti ada pengaruh pemberian terapi musik klasik Mozart dalam menurunkan kecemasan pasien pre operasi.

Hasil penelitian ini sejalan dengan penelitian yang dilakukan oleh Devi (2008), bahwa ada perbedaan yang signifikan kecemasan pasien sebelum dan sesudah intervensi pada kelompok intervensi dengan $\mathrm{P}$ value 0,001 di RS Cipto Mangunkusumo Jakarta. Sejalan juga dengan penelitian Qulsum dkk (2012), di dapat bahwa ada perbedaan yang signifikan kecemasan pasien sebelum dan sesudah intervensi pada kelompok intervensi dengan $\mathrm{P}$ value 0,000 di RSUD Tugurejo Semarang. Hasil penelitian Simbolon, (2015), tentang pengaruh terapi musik terhadap tingkat kecemasan pada pasien pre operasi di ruang rawat bedah RS Santa Elisabeth Medan menunjukkan bahwa terdapat pengaruh bermakna antara terapi musik terhadap perubahan tingkat kecemasan pada pasien pre operasi.

Potter dan Perry (2010), menjelaskan bahwa tindakan keperawaan untuk menangani kecemasan pasien yaitu berupa tindakan mandiri, contohnya seperti teknik relaksasi dan distraksi. Distraksi merupakan tindakan mengalihkan perhatian dan bekerja memberikan pengaruh yang baik untuk jangka waktu yang singkat. Salah satu teknik distraksi yang digunakan untuk mengatasi kecemasan adalah dengan mendengarkan musik klasik.

Peneliti menyimpulkan bahwa pasien pre operasi yang mengalami kecemasan mengalami penurunan tingkat kecemasan setelah diberikan terapi musik klasik karya Mozart. Hal ini disebabkan karena musik klasik yang mempunyai katagori alfa dan tetha 5000-8000 Hz dapat merangsang tubuh dan pikiran menjadi lebih rileks sehingga merangsang otak mengahasilkan hormon serotonin dan hromon endorphin yang menyebabkan tubuh menjadi rileks dan membuat detak jantung menjadi stabil (Muntisari dkk, 2014).

\section{KESIMPULAN DAN SARAN}

\section{Kesimpulan}

1. Kecemasan pasien Pre Operasi Sebelum Diberikan Terapi Musik Klasik di Instalasi Bedah Pusat RSUP. H. Adam Malik Medan didapatkan mayoritas pasien berada di kecemasan sedang yaitu 24 orang (75\%), kecemasan berat sebanyak 8 
orang $(25 \%)$ dan tingkat kecemasan ringan serta panik tidak ada

2. Kecemasan pasien Pre Operasi Setelah Diberikan Terapi Musik Klasik terdapat perubahan tingkat kecemasan pasien ringan $(0,0 \%)$ menjadi 10 orang $(31,3 \%)$, Sedang sebanyak 24 Orang $(75 \%)$ menjadi 20 orang $(62,5 \%)$ dan berat sebanyak 8 orang (25\%) menjadi 2 orang $(6,2 \%)$.

3. Pengaruh terapi musik terhadap kecemasan pre operasi di Instalasi Bedah Pusat RSUP. H. Adam Malik Medan menunjukkan p value $=0.00$, dan $0.000<0,05$ yang berarti ada pengaruh yang signifikan dari pemberian terapi musik klasik pada uji $\mathrm{T}$ yaitu sebelum diberikan terapi musik didapat hasil uji $t$ 382,5 menjadi $301,3(81,2)$.

\section{Saran}

Berdasarkan kesimpulan di atas saran-saran yang dapat disampaikan diantaranya yang ditujukan kepada:

1. Bagi Institusi RSUP. H Adam Malik Diharapkan menjadi pertimbangan rumah sakit atau perawat untuk menjadikan terapi musik sebagai salah satu intervensi keperawatan dalam membantu meringan kan kecemasan pada pasien pre operasi yang mengalami kecemasan.

2. Bagi Pendidikan Keperawatan
Hasil penelitian ini dapat menambah wawasan dan pengetahuan tentang terapi musik klasik dalam penanganan kecemasan

3. Bagi Peneliti Keperawatan

Diharapkan pada peneliti selanjutnya sebagai bahan tambahan untuk referensi ilmu keperawatan. Penelitian selanjutnya diharapkan menggunakan desain penelitian yang lain seperti case control Study yang dapat membandingkan tingkat kecemasan yang diberi terapi musik klasik dengan yang tidak diberi terapi musik klasik.

\section{DAFTAR PUSTAKA}

Andiyani, R, dkk. (2014). Pengaruh Terapi Musik Terhadap Tingkat Kecemasan Pasien Pre Operasi Sectio Caesaria. Jurnal Husada Mahakam Volume III No. 7, Mei 2014, Hal.319

387.https://husadamahakam.files.wor dpress.com/2015/07/4-edi-2-terapimusik-350-358.pdf. Diakses pada tanggal 16 Sepetember 2017.

Arikunto, S. (2010). Prosedur Penelitian Suatu Pendekatan Praktik, Ed. Revisi VI. Jakarta: Penerbit PT Rineka Cipta.

Astuti, A., \& Merdekawati, D. (2016). Pengaruh Terapi Musik Klasik Terhadap Penurunan Tingkat Skala Nyeri Pasien Post Operasi. Jurnal Ipteks Terapan Research of Applied Science And Education V10.I3 (148154) Diakses dari http://ejournal.kopertis10.or.id/index. php/jit/article/view File/526/114. Diakses pada tanggal 16 September 2017. 
Campbell, D. T., \& Cronbach. (2002). Experimental and quasi experimental designs for generalized causal inference. USA: Houghton Mifflin Company.

Devi, D. (2008). Pengaruh terapi musik terhadap respon psikofisiologis pasien yang menjalani coronary angigraphy di Pelayanan Jantung RSU Cipto Mangunkusumo. Jakarta

Djohan. (2006). Terapi Musik, Teori dan Aplikasi. Yogjakarta: Galangpress

Hawari, D. (2011). Manajemen Stres Cemas dan Depresi. Jakarta: Balai Penerbit FKUI.

Kaplan., \& Saddock. (2010a). Sinopsis Psikiatri. Tanggerang: Binarupa Aksara.

Kaplan., \& Saddock. (2010b). Buku Ajar Psikiatri Klinik. Jakarta: EGC.

Muttaqin, A., \& Kurmala, S. (2009). Asuhan Keperawatan Klien Dengan Gangguan Sistem Kardiovaskular dan Hematologi. Jakarta: Salemba Medika.

Muntisari dkk. (2014). Pengaruh pemberian Terapi Musik Klasik Terhadap Penurunan Depresi Pada Pasien Stroke Non-Hemoragik di RSUD Salatiga.

Potter, A., \& Perry, A.G. (2010). Fundamental Keperawatan, Ed 8, buku 1. Jakarta: Salemba Medika.

Puri, B. K, dkk. (2012). Buku Ajar Psikiatri (edisi kedua). Jakarta: EGC.

Qulsum dkk. (2012). Perbedaan tingkat kecemasan pada pasien pre Operasi Sebelum dan Sesudah Pemberian Terapi Musik Klasik di RSUD Tugurejo

Savitri, W., dkk. (2016). Terapi Musik dan Tingkat Kecemasan Pasien Pre Operasi. Media Ilmu Kesehatan Vol, No 1 April 2016. Diakses dari https:// www.researchgate.net/profile/wenny savitri/publication/31668184 Diakses pada tanggal 16 September 2017

Simbolon, P. (2015). Pengaruh Terapi Musik Terhadap Tingkat Kecemasan pada Pasien Pre Operasi di Ruang Rawat Bedah RS santa Elisabeth Medan. 